This is a draft chapter. The final version is available in the Research Handbook on International Law and Social Rights, edited by Christina Binder, Flavia Piovesan, Amaya Úbeda de Torres and Jane

Hofbauer, Edward Elgar Publishing Ltd, 2020: 519-534.

https://doi.org/10.4337/9781788972130.00044

The material cannot be used for any other purpose without further permission of the publisher, and is for private use only.

\title{
International Criminal Law and Social Rights
}

Evelyne Schmid*

\section{Introduction}

Abuses of social rights raise legal questions in international criminal law and in transitional justice more broadly. Conduct that affects people's enjoyment of social rights is common in many situations in which international crimes are committed, particularly in situations of armed conflict. ${ }^{1}$ Such abuses can include the destruction of the livelihoods of a population, the often-associated forced displacement, looting or destruction of property and other abuses that can constitute violations of social rights. In line with the focus of this Research Handbook, the term social rights is used loosely in this chapter to take into account those rights that are particularly crucial to achieve 'a society which protects and advances the enjoyment of basic human needs and ensures the material conditions for a life in dignity', ${ }^{2}$ such as the right to food, housing, social security, work, health or education.

Twenty years since the establishment of the International Criminal Court (ICC), after more than fifty truth commissions ${ }^{3}$ and countless initiatives to deal with past injustices following armed conflicts or other situations of violence, it does not seem unusual that societies try to punish at least some so-called civil and civil human rights violations. In contrast, the analysis of social rights dimensions of past injustice is a rarer part of what is now known as transitional justice, ${ }^{4} i . e$. the 'processes and mechanisms associated with a society's attempt to come to terms with a legacy of large-scale past abuses' ${ }^{5}$ Such attempts include criminal proceedings but also other approaches that often take international criminal law as at least one of their normative frameworks. [end of page 519]

\footnotetext{
* Some of the text of this chapter is based on the following previous publications by the same author, notably Evelyne Schmid, Taking Economic, Social and Cultural Rights Seriously in International Criminal Law (2015); ibid., 'Möglichkeiten und Grenzen des Völkerstrafrechts als Instrument gegen die illegale Ausbeutung von natürlichen Ressourcen und Landraub' (2017) 6 Zeitschrift für Friedens- und Konfliktforschung 129; ibid., 'L'économie' in O Beauvallet (ed.), Dictionnaire encyclopédique de la justice pénale internationale (2017) 383. I warmly thank Nitya Duella, BSc, for proofreading the manuscript.

1 \#\#Reference to Amrei Müller's chapter in this RHB.

2 \#\#Reference C Binder and others, 'Introduction [?? Or Preface Etc.]'.

${ }^{3}$ Priscilla Hayner, Unspeakable Truths: Transitional Justice and the Challenge of Truth Commissions (2011).

${ }^{4}$ Louise Arbour, 'Economic and Social Justice for Societies in Transition' (2007) 40 New York University Journal of International Law and Politics 1; Zinaida Miller, "Effects of Invisibility: In Search of the "Economic" in Transitional Justice' (2008) 2 International Journal of Transitional Justice 266; Dustin Sharp, 'Interrogating the Peripheries: The Preoccupations of Fourth Generation Transitional Justice' (2012) 26 Harvard Human Rights Journal 149.

${ }^{5}$ Secretary-General, Guidance Note of the Secretary-General on the United Nations Approach to Transitional Justice (March 2010) 2.
} 
Explicitly or implicitly, many international criminal lawyers have taken it for granted that international criminal law deals with abuses of certain civil and political rights and excludes conduct affecting social rights. Some have dismissed - at least until very recently - the legal feasibility of addressing economic, social or cultural rights abuses within the framework of criminal law. ${ }^{6}$ Sometimes, economic, social and cultural rights abuses are relegated to the background, as if they are significant only as the context they provide to other serious crimes. Yet, as this chapter will demonstrate, considerations of social rights abuses were part and parcel of international criminal law since its very beginning.

Over the last decade, in the aftermath of various mass atrocities, scholars, the United Nations and policymakers have called attention to the denial of access to food, water, work, education, health and other economic or social rights. In 2006, Louise Arbour, the former High Commissioner for Human Rights, asserted that efforts to address the legacy of widespread human rights abuses are biased toward civil and political rights. She stated the need for further exploration of 'the use of statutes of existing international and national courts to adjudicate economic, social, and cultural violations as international crimes'. ${ }^{7}$

In the meantime, many accepted Arbour's invitation to reconsider traditional assumptions and examine the relevance of social rights abuses to established processes dealing with the legacy of past crimes. ${ }^{8}$ The Secretary General emphasizes that '[i]nvestigating and prosecuting crimes under national or international law where the conduct involves violations of economic, social and cultural rights as well as civil and political rights' is part of the UN approach to transitional justice. ${ }^{9}$ Pablo de Greiff, the first Special Rapporteur on the promotion of truth, justice, reparation and guarantees of non-recurrence, stressed in his initial report that the developments in the Middle East and North Africa after 2011 testify to the relevance of the 'prominent role that claims relating to economic rights occupy in these transitions; claims against corruption and in favour of economic opportunities have been raised at par in the regions with claims for the redress of violations of civil and political rights'. ${ }^{10}$ In this chapter, I present a condensed overview of the idea that certain abuses of social rights can overlap with existing definitions of international crimes. The analysis is then broadened to include at least three other ways of how social rights abuses can be relevant to international criminal law. Arguably, social rights abuses can trigger or facilitate the commission of international crimes or the outbreak of conflict and violence (I call this the 'root causes argument'). Moreover, the commission of international crimes can have severe consequences on the enjoyment of social rights, for instance in the case of remaining family members of [end of page 520] a disappeared person. Lastly, the decision to initiate prosecutions for international crimes can have implications for social rights protection.

The chapter is structured in the following way. It will introduce the legal framework by defining international criminal law and by outlining how it can interact with human rights law, with an emphasis on social rights enjoyment (section II). Section III will provide an overview of the various factual and legal relationships between social rights and international criminal law. At the end of the chapter, I discuss the prospects of the ICC engaging more with social rights and conclude with some reflections

\footnotetext{
${ }^{6}$ See below, section III.A; for references to authors who suggest that current international criminal law cannot address social rights, see $\mathrm{n} 29$.

${ }^{7}$ Arbour (n 4), 9-10, 15-16 and note 26.

${ }^{8}$ The International Journal of Transitional Justice dedicated a special issue to transitional justice and development with a series of articles dedicated to ESCR. For the editorial, see R Mani, 'Dilemmas of Expanding Transitional Justice, or Forging the Nexus between Transitional Justice and Development' (2008) 2 International Journal of Transitional Justice 253.

${ }^{9}$ Secretary-General (n 5), 10. The UN Office of the High Commissioner for Human Rights prepared a 'Special Issue on Transitional Justice and Economic, Social and Cultural Rights'. OHCHR, Transitional Justice and Economic, Social and Cultural Rights (2014).

10 Pablo de Greiff, 'Report of the Special Rapporteur on the Promotion of Truth, Justice, Reparation and Guarantees of Non-Recurrence’ UN Doc A/HRC/21/46 (2012), para 17.
} 
on the major limitations but also the possibilities of using international criminal law as a tool to increase social rights protection.

\section{Legal Framework}

In a first step, I will briefly clarify the use of the term international criminal law in this chapter and will then go on to examining how international criminal law relates to human rights law and why it is crucially important to keep in mind the distinctiveness of these branches of international law.

\section{a. Definition of International Criminal Law}

International criminal law is not limited to those crimes over which the ICC has jurisdiction. The Rome Statute is a useful starting point to understand the elements of some international crimes, however, it is important to stress that states only chose to entrust the ICC with jurisdiction over a limited number of international crimes. ${ }^{11}$ Understandings of the term 'international criminal law' vary. ${ }^{12}$ In this Chapter, international crimes are understood to encompass all those crimes for which the following two cumulative features are present: ${ }^{13}$

First, for all international crimes, international law foresees mechanisms for international cooperation and enforcement in the repression of certain conduct, such as international tribunals, mandatory or permissive universal jurisdiction or obligations to cooperate in criminal matters. Second, to constitute an international crime, international law must either directly establish criminal liability at the international level or require states to criminalize conduct in domestic criminal law. ${ }^{14}$ The most wellknown groups of international crimes - genocide, crimes against humanity, aggression and war crimes - are examples of crimes that are criminalized at the international level itself. ${ }^{15}$ Some authors limit their use of the term 'international criminal law' to the body of law dealing with these crimes only; ${ }^{16}$ sometimes the focus is narrowed further to concentrate on the definition of those crimes as they are contained in the Rome Statute of the ICC. ${ }^{17}$ Other international crimes deal with conduct that is not directly criminalized [end of page 521] by general international law, but conduct that states must, by virtue of international law, criminalize in their domestic legal systems. Some authors refer to these crimes as 'transnational' or 'treaty-based'. ${ }^{18}$ The perpetrator does not incur penal responsibility directly under international law, but indirectly under national criminal laws, which the state must adopt by virtue of international legal obligations to criminalize the conduct. Such obligations are contained in treaties and sometimes in customary international law to the extent that the treaty provisions reflect custom. Because the criminal conduct actually or potentially affects the interests of more than one state, there is a mutual interest in suppressing these crimes. Such crimes include, among others, slavery-related practices, certain forms of corruption, money-laundering, movements of hazardous waste or apartheid and torture.

\footnotetext{
${ }^{11}$ Rome Statute of the International Criminal Court (17 July 1998) 2187 UNTS 90, Arts 10 and 22(3).

${ }^{12}$ Robert Cryer, An Introduction to International Criminal Law and Procedure (2007) 4.

13 This section is based on Schmid $2015(\mathrm{n} *)$, chapter 1.

${ }^{14}$ Cryer (n 12), 4-6 (who limits the term 'international criminal law' to the first category).

${ }^{15}$ Yoram Dinstein, 'International Criminal Law' (1985) 20 Israel Law Review 206, 221.

${ }^{16}$ Neil Boister, 'Transnational Criminal Law?' (2003) 14 European Journal of International Law 953, $961 \mathrm{ff}$.

${ }^{17}$ Crimes under the Rome Statute are sometimes labelled as so-called 'core crimes' but there is no reason to exclude other crimes from the analysis. For recent definitional discussions, see in particular Harmen van der Wilt and Christophe Paulussen, Legal Responses to Transnational and International Crimes (2017).

${ }^{18}$ Boister (n 16), 953.
} 
Social rights are defined in international human rights law, not in international criminal law. If we want to identify the precise relationship between international criminal law and social rights, it is necessary to clarify how international criminal law and international human rights law relate to each other. This is the purpose of the next section.

\section{b. Assessing the Relationship Between International Criminal Law and Human Rights Law}

By far not every violation of human rights is an international crime. The protection of human dignity plays a central role in the development of both international criminal law and human rights law, but there is no convergence. The two bodies of law follow different logics and pursue different purposes. ${ }^{19}$ Human rights treaties are concluded by states. At least as human rights law is traditionally understood, to identify a violation of social rights, it is necessary to attribute relevant conduct to a state based on the customary rules on the responsibility of states for internationally wrongful acts. ${ }^{20}$ The protection of social rights in human rights law, therefore, focuses primarily on the role of the state, including its role in interfering with rights enjoyment and taking, or failing to take, positive measures to protect and fulfil social rights. All states have ratified international treaties and are bound by customary international law norms that require them to respect, protect and fulfil human rights; i.e. states must not fail to respect rights by unlawfully interfering with the enjoyment of existing rights (e.g. by arbitrarily evicting people from their homes); states must protect individuals from interference by third parties (e.g. protection from health-endangering environmental pollution by private companies); and states have moreover undertaken to fulfil the complete realization of these rights to the extent possible (e.g. by taking measures to improve access to vocational [end of page 522] education). ${ }^{21}$ Where the state does not breach an international obligation, there is no human rights violation - at least as traditionally understood. ${ }^{22}$

On the other hand, international criminal law focuses on the individual responsibility of persons, such as commanders of armed forces or rebel groups, government officials, corporate executives, soldiers or whoever else meets the objective and the mental elements of an offence that constitutes an international crime. International criminal law is primarily a tool to decide on the guilt or innocence of individuals accused of criminal conduct and to establish mechanisms of cooperation between states in the repression of certain conduct. 'In so doing, international criminal law aims to serve an indirect protective purpose [ideally] by deterring future crimes and by affirming the importance of the normative values protected. ${ }^{23}$

The task of judges at an international criminal tribunal consists of assessing whether the elements of specific crimes are met; an international criminal judge is not tasked in analyzing whether state responsibility has been engaged in the commission of these crimes. ${ }^{24}$ Given this fundamental distinction

\footnotetext{
19 \#reference to Amrei Müller, 'Social Rights in Armed Conflict Situations' in this RHB; see also Andrew Clapham, 'Human Rights and International Criminal Law' in William Schabas (ed.), The Cambridge Companion to International Criminal Law (2016) 11; Hans-Peter Gasser, 'The Changing Relationship Between International Criminal Law, Human Rights Law and Humanitarian Law' in Jose Doria et al. (eds), The Legal Regime of the International Criminal Court: Essays in Honour of Professor Igor Blishchenko (2009) 111.

${ }^{20}$ UNGA Res A/56/83 (12 December 2001) Articles on the Responsibility of States for Internationally Wrongful Acts (ARSIWA), Arts 4-11.

${ }^{21}$ \#\#Reference to Sepulveda's chapter in this RHB.

${ }^{22}$ For the argument that non-state actors can commit human rights violations, see most notably A Clapham, Human Rights Obligations of Non-State Actors (2006).

${ }^{23}$ Schmid $2015(\mathrm{n} *), 68$. For a summary of the approaches to justify the use of international criminal law, see Cryer (n 12), 22ff.

${ }^{24}$ For the outline of the distinctions between state responsibility and individual criminal liability, see Andrea Bianchi, 'State Responsibility and Criminal Liability of Individuals' in Antonio Cassesse (ed.), The Oxford Companion to International Criminal Justice (2009) 16.
} 
between the law of state responsibility for human rights violations and international criminal law, it is entirely unsurprising that the number of international criminal cases with explicit references to social rights is very limited. To identify the area of overlap between international crimes and social rights (or other human rights), we must ourselves complement the international criminal law analysis with an analysis of human rights law. Criminal tribunals do not generally refer to social or other human rights abuses because no criminal court prosecutes human rights violations as such, independent of whether they concern civil, political, economic, social or cultural aspects. ${ }^{25}$ Rather, the instruments of international criminal law define crimes by their specific objective and subjective (mental) elements. These elements of crimes, just like in domestic criminal law, delineate the conduct that constitutes an international crime. Lawyers apply these elements of a crime to concrete factual scenarios to decide on the criminality of the examined conduct. This logic applies irrespective of the type of underlying abuse. Hence, even if there are few cases in which international criminal tribunals have explicitly referred to social rights, ${ }^{26}$ this observation does not imply that social rights abuses are not relevant for international criminal law. In the following sections, we will consider examples that illustrate how the elements of some important international crimes can overlap with conduct pertaining to the protection of social rights and in what other ways social rights abuses can be related to international criminal law. [end of page 523]

\section{How Social Rights are Relevant to International Criminal Law}

Social rights are relevant to international criminal law in multiple ways. As mentioned in the introduction, these relationships can be grouped into four categories. First, the commission of an international crime may overlap with abuses of social rights; this is the area of legal overlap between the two branches. Second, abuses of social rights can be the root causes or drivers of the commission of international crimes. Third, international crimes can have negative consequences on the enjoyment of social rights. Fourth and finally, criminal prosecutions or other transitional justice approaches relying on international criminal law can arguably influence social rights protection, both positively and negatively.

a. The Same Factual Background May Constitute an International Crime and a Violation or an Abuse of Social Rights

We will first consider situations that can be described simultaneously as a violation or an abuse of a social right and as an international crime. In other words, this section deals with the area of overlap between substantive definitions of international crimes on the one hand and social rights violations or abuses on the other hand. ${ }^{27}$ In these scenarios, social rights abuses are directly relevant for international criminal law as part of the factual scenario that might lead to a criminal conviction.

In previous research, I presented evidence that all four groups of war crimes, at least eight of the crimes against humanity, genocide and a number of other offences in treaties that contain obligations for states to criminalize harmful offences in their domestic law can overlap with economic, social and cultural rights violations. ${ }^{28}$ My findings are contrary to widespread expectations that dealing with social rights (and their economic or cultural 'siblings') in processes aimed at addressing past abuses is a departure

\footnotetext{
${ }^{25}$ Schmid 2015 (n*), 67-73.

${ }^{26}$ The most notable exception is the Kupreškić trial judgment in which the ICTY explicitly referred to economic and social rights, notably in relation to housing, education and health as the underlying issues. Prosecutor $v$ Kupreškić, IT-95-16-T, 14 January 2000, paras 597, 599, 615, 630, 634. Yet, a legal finding of state responsibility for violations of human rights is not required by an international criminal tribunal.

${ }^{27}$ The term 'violation' is reserved for social rights abuses in which conduct is attributable to a state, e.g., because the state interferes with rights or because it fails to protect against abuses despite having the means and knowledge to avoid harm. The term 'abuse' is used to designate harm to social rights enjoyment without necessarily constituting a violation of human rights law.

${ }^{28}$ In more detail, Schmid 2015 (n*).
} 
from the original conceptions of international criminal law (and of transitional justice more broadly). I call this the 'legal impossibility argument': Several authors explicitly state that contemporary international criminal law prescribes an exclusive or at least a primary focus on civil and political rights. According to this view, such a focus is obvious from the provisions containing the current definitions of international crimes..$^{29}$ Hence, it is often taken for granted that the international crimes set out in the Rome Statute and in other sources are relevant to civil and political rights violations and exclude considerations of economic, social or cultural rights. Such statements suggest that the hierarchical treatment of human rights in international criminal law is a necessary consequence of [end of page 524] existing international law as such rather than its interpretation and application. ${ }^{30}$ Yet, the research I conducted revealed that these assumptions are inaccurate and we do not need to expand international law in order to pay attention to at least some social rights considerations within international criminal law. Some of the earliest materials on international criminal law already indicate that abuses of socioeconomic and cultural rights have always been part of the thinking on international criminal law. The following sub-sections provide illustrations of the neglected overlap between social rights and existing definitions of international crimes. ${ }^{31}$

\section{i. Crimes against Humanity and Genocide}

Crimes against humanity are the group of international crimes for which the largest amount of information relevant to the overlap with social rights is available. This is because the legal development of crimes against humanity was inspired by the international community's desire to punish mass abuses of human rights by states against their own citizens. ${ }^{32}$ Within the category of crimes against humanity, the offence of forcible transfer often goes hand in hand with abuses of social and economic rights, particularly forced evictions or deliberately imposed discriminatory measures in the realm of people's access to jobs and livelihoods. ${ }^{33}$ The destruction of livelihoods, by burning victims' homes for example ${ }^{34}$ or by singling out inmates in prisons for starvation and forced labour, can constitute a serious deprivation of fundamental rights for the purpose of a persecution charge. ${ }^{35}$ The following examples from the case law of international criminal tribunals are straightforward illustrations of conduct that is recognized as crimes against humanity (or genocide or war crimes - depending on the legal qualification of the situation and the intent with which the conduct was inflicted): The hindrance of humanitarian assistance, ${ }^{36}$ contaminating water sources ${ }^{37}$ and withholding essential (and available) medicine, food ${ }^{38}$ or water ${ }^{39}$ to individuals under one's control. Apart from constituting international crimes, such conduct

\footnotetext{
${ }^{29}$ Paul D Ocheje, 'Refocusing International Law on the Quest for Accountability in Africa: The Case against the “Other” Impunity' (2002) 15 Leiden Journal of International Law 749, 779; Lars Waldorf, 'Anticipating the Past: Transitional Justice and Socio-Economic Wrongs' (2012) 21 Social \& Legal Studies 171, 173. With more nuance: Larissa Van den Herik, 'Economic, Social and Cultural Rights - International Criminal Law's Blind Spot?' in Eibe Riedel, Gilles Giacca and Christophe Golay (eds), Economic, Social, and Cultural Rights: Contemporary Issues and Challenges (2014) 343, 344.

${ }^{30}$ Schmid $2015(\mathrm{n} *)$, chapter 2.

${ }^{31}$ Further references and a more detailed analysis, Schmid 2015 (n *), chapters 4-7.

${ }^{32}$ For an outstanding account, see Philippe Sands, East West Street: On the Origins of Genocide and Crimes against Humanity (2017).

${ }_{33}$ Prosecutor v Krajišnik, ICTY, IT-00-39-T, 27 September 2006, para 729.

${ }^{34}$ Kupreškić (n 26), para 336.

${ }^{35}$ Report of the Commission of Inquiry on Human Rights in the Democratic People's Republic of Korea, (7 February 2014) A/HRC/25/CRP.1, paras 1084 and 1115ff.

${ }^{36}$ Second Decision on the Prosecution's Application for a Warrant of Arrest against Al Bashir, 12 July 2010, PreTrial Chamber I of the ICC, ICC-02/05-01/09, para 35.

${ }^{37}$ Ibid., paras 37-38.

${ }^{38}$ Prosecutor v Delalić, ICTY, IT-96-21-T, 16 November 1998, paras 1092-1996.

${ }^{39}$ Ibid., paras 1097-1100. United States of America $v$ Toshino et al., US Military Commission at Yokohama, Case No 154, 4 May 1948.
} 
can potentially also constitute violations of social or economic rights, such as violations of the right to freedom from hunger, the right to an adequate standard of living or the right to health.

Genocide is a particularly complex offence and social rights abuses can play a decisive part in genocidal conduct. To Raphaël Lemkin, the driving force behind the Genocide Convention, there is a central relationship between abusive social, economic and cultural policies and the definition of genocide. ${ }^{40}$ Genocide is a complex offence because it requires proof of a dolus specialis (specific intent) to destroy a protected group. Despite prevailing interpretations [end of page 525] that the verb 'destroy' is limited to the 'physical or biological' destruction of a group ${ }^{41}$ social rights dimensions of genocide remain part of the existing law in ways that are often unacknowledged by scholars and tribunals. ${ }^{42}$ A perpetrator intending to displace, starve or otherwise deprive a protected group of access to essential social rights enjoyments can have the requisite genocidal intent if he or she aims, by his or her conduct, to destroy the group in whole or in part. It does not matter if the perpetrator summarily executes members of the group or denies them of access to essential food, health, water, sanitation or lifesaving health care. As the International Criminal Tribunal for Rwanda (ICTR) explained in Akayesu, all 'methods of destruction by which the perpetrator does not immediately kill the members of the group, but which, ultimately, seek their physical destruction' may constitute genocidal acts, ${ }^{43}$ and may consequently attract genocidal intent. Kress correctly points out that the verb 'destroy' must 'not be reduced to the physical destruction of the members of the group as it exists at the time of the overall genocidal campaign but must extend to all possible results of overall campaigns which take the form of a pattern of one or more prohibited acts'. ${ }^{44}$ It is, therefore, necessary to take into account a possible (real or merely intended) ${ }^{45}$ temporal lag between the commission of abuses and the intended destruction. One should not limit the analysis by taking an unwarrantedly narrow conception of immediate physical violence involving gunfire, machetes or gas chambers. If these considerations are born in mind, social rights abuses squarely play a role in the law on genocide and existing case law has dealt with abuses that human rights lawyers today qualify as social rights abuses. ${ }^{46}$

ii. War Crimes

International criminal law deals with a large number of war crimes, some of which are specific to armed conflicts of an international character and some of which attract special legal consequences (so-called grave breaches) ${ }^{47}$ For the purpose of this chapter, let us consider a few examples how social rights can relate to war crimes. [end of page 526]

\footnotetext{
${ }^{40}$ Raphaël Lemkin, Axis Rule in Occupied Europe (1944).

${ }^{41}$ For example, Application of the Convention on the Prevention and Punishment of the Crime of Genocide (Bosnia and Herzegovina v Serbia and Montenegro) 2007 ICJ 43, 185, para 344 (Judgment of 26 February). Prosecutor v Krstić, ICTY, IT-98-33-T, 2 August 2001, para 580.

42 Evelyne Schmid, 'Genocide \& Socio-Economic Rights: A Response' (IntLawGrrls, 2012) $<$ http://www.intlawgrrls.com/2012/03/genocide-socio-economic-rights-response.html $>$ (3 June 2019). Schmid $2015(\mathrm{n} *)$, chapter 6.

${ }^{43}$ Prosecutor v Akayesu, ICTR, ICTR-96-4-T, 2 September 1998, para 505.

${ }^{44}$ Claus Kress, 'The Crime of Genocide under International Law' (2006) 6 International Criminal Law Review 487.

${ }^{45}$ The actual result of group destruction must not occur for a finding of genocide.

${ }^{46}$ See notably the judgment against Hauptsturmführer Amon Göth, in which the tribunal explicitly refers to the 'economic, social and cultural connotations' of the crime of genocide. Prosecutor $v$ Göth, Case No 37, VII Law Reports of War Criminals 1, 5 September 1946, Supreme National Tribunal of Poland 8.

${ }^{47}$ It is recommended that readers consult the specialized literature on war crimes for the various distinctions between different types of war crimes. For war crimes included in the Rome Statute, e.g., Knut Dörmann, Louise Doswald-Beck and Robert Kolb, Elements of War Crimes under the Rome Statute of the International Criminal Court: Sources and Commentary (2003). For war crimes in non-international armed conflicts (Rome Statute and beyond): Eve La Haye, War Crimes in Internal Armed Conflicts (2010).
} 
Arthur Greiser, a 'model Nazi' 48 and the territorial leader (Gauleiter) of the Warthegau in Poland, was convicted of crimes against humanity and war crimes based on his dreadful policies against the Polish population during World War II. If we study his trial from a contemporary human rights perspective, the documents read like a primer of how international crimes can be committed by way of very serious violations of victims' social, economic and cultural rights - including the right to education, food, health, housing and work and the right to take part in cultural life. Most notoriously, Greiser introduced a set of regulations that 'completely deprived the Poles of all rights to real property ..., deprived the Poles of the right to choose their employment, fixed their conditions of employment and wages, of the scale of nourishment, terms of health and other social services for the Poles at a considerably lower level than that for the Germans; ... forbade their taking any part in cultural life or sport, and compulsorily limited the education of Polish children to its elementary stages only'. ${ }^{49}$ Unfortunately, his trial has been almost completely forgotten despite the fact that Greiser was the very first individual ever convicted in accordance with the Nuremberg Charter. ${ }^{50}$

In the interest of being succinct, an additional recent and interesting example must suffice. The Trial Chamber II of the ICC, e.g., recognized that the theft of household items, food or livestock can have extremely serious consequences for the daily life of survivors and can constitute the ancient war crime of pillage. ${ }^{51}$ In situations in which individuals acting on behalf of a state commit the pillage, it is possible to identify a war crime as well as a violation of, for instance, the right to food.

\section{iii. Other Crimes}

Many international crimes not included in the Rome Statute can also have close relationships with abuses of social rights - slavery-related practices, apartheid, the laundering of proceeds of crime or corruption being just some examples. ${ }^{52}$ For instance, victims of human trafficking are victims of a criminalized contemporary slavery-related practice and are often simultaneously prevented from exercising their right to social security. Where states fail to protect victims despite the knowledge of their plight, the situation in which the international crime of trafficking is committed can at the same time constitute a violation of social rights. Corruption is another offence which states agreed, by virtue of international treaties, to criminalize in their domestic legal system, ${ }^{53}$ and is, therefore, the subject of international (or transnational) criminal law. ${ }^{54}$ Under certain (rather narrow) circumstances, corruption can itself constitute a violation of social rights. ${ }^{55}$ Moreover, a state that takes insufficient [end of page 527] action against corruption or is itself involved in corrupt practices will often fail to fulfil social rights. The African Commission on Human and Peoples' Rights found that the right to education is violated if schools are closed for two years without explanation and if teachers are not paid because of widespread corruption. ${ }^{56}$ By the same mechanism, a state tolerating corruption can also violate its duty

\footnotetext{
${ }^{48}$ Catherine Epstein, Model Nazi: Arthur Greiser and the Occupation of Western Poland (2010).

${ }^{49}$ Prosecutor v Greiser, Case No 74, XIII Law Reports of Trials of War Criminals 70, 7 July 1946, Supreme National Tribunal of Poland 73.

${ }^{50}$ For more analysis on his trial, see Mark Drumbl, "Germans Are the Lords and Poles Are the Servants": The Trial of Arthur Greiser in Poland, 1946' in Kevin Heller and Gerry Simpson (eds), The Hidden Histories of War Crimes Trials (2013) 411; Schmid 2015 (n*), 166-170.

51 Prosecutor v Katanga, Trial Chamber II of the ICC, Judgment Pursuant to Article 74 of the Statute, 7 March 2014, No ICC-01/04-01/07, para 953.

${ }^{52}$ For more analysis, Schmid $2015(\mathrm{n} *)$, chapter 7.

${ }^{53}$ For example, United Nations Convention against Corruption (31 October 2003) 2349 UNTS 41.

${ }^{54}$ For the definitional delimitations of international criminal law, see section II.a.

55 \#\#Reference to Kolawole's chapter in this RHB.

${ }^{56}$ Free Legal Assistance Group and Others v Zaire, ACHPR, Communications 25/89, 47/90, 56/91, 100/93, 1 October 2005. See also Paolo Mauro, 'Corruption and the Composition of Government Expenditure' (1998) 69 Journal of Public Economics 263, at 264, finding a correlation between corruption and lower levels of investment in education. The Inter-American Commission on Human Rights has equally expressed concern about the negative
} 
to fulfil the right to social security. As Bacio Terracino explains, 'embezzlement from a pension scheme will reduce the resources available for retired people and can result in payments that are not sufficient for living, ${ }^{57}$

These examples illustrate how violations and abuses of social rights can overlap with existing definitions of international crimes. As a consequence, there is no legal justification for claiming that social rights problems are categorically excluded from the scope of the existing mechanisms that rely on international criminal law.

\section{b. Social Rights Violations as Causes or Drivers of International Crimes?}

International criminal law also has links with social rights insofar as widespread abuses of social rights and a generally weak protection of the population's enjoyment of these rights, high levels of inequality and a discontent with the state, may cause or reinforce cleavages that can lead to armed conflicts or other situations in which international crimes are committed. Several truth commissions and academic reports suggested, e.g., links between economic marginalization and discrimination with regards to the access to social rights and the commission of international crimes (e.g. truth commissions in Guatemala, Kenya, Liberia, Sierra Leone or Timor Leste) ${ }^{58}$ Political scientists caution against deterministic and mono-causal explanations of the outbreak of civil war or other types of unrest. The reasons for the outbreak of violence are complex and there is rarely a single cause. ${ }^{59}$ That said, socio-economic variables do seem to play a role. ${ }^{60}$

Another aspect must be treated with caution. Care must be taken not to equate the legal term of 'violations of social rights' with all types of unpleasant socio-economic aspects of a society's current or past situation. Although violations of social rights, root causes or drivers of a conflict, structural inequality and other socio-economic problems can all be related, it is often inaccurate to equate them without further explanation. Conflating these terms risks undermining advances made in the protection of social rights as legal rights because the [end of page 528] conceptual confusion easily contributes to the inaccurate impression that all social rights issues are always vague and dealing with any aspect of social rights would inherently overburden transitional justice approaches. ${ }^{61}$ Yet, it is fair to argue that a widespread lack of social rights protection tends to increase the population's dissatisfaction with the government and correlates with other indicators that point to possible danger. ${ }^{62}$ On that basis, the United

effects of corruption on social rights, see its Resolution 1/18 on Corruption and Human Rights (2 March 2018), section 3.

${ }^{57}$ Julio Bacio Terracino, 'Hard Law Connections between Corruption and Human Rights' (Review Meeting: Corruption and Human Rights) 30; <www.ichrp.org/en/projects/131> (16 July 2019).

${ }^{58}$ For the experiences of truth commissions, see in particular OHCHR (n 9). More recently Amanda Cahill-Ripley and Diane Hendrick, Economic, Social and Cultural Rights and Sustaining Peace: An Introduction (2018).

${ }^{59}$ For example, Jeffrey Dixon, 'What Causes Civil Wars? Integrating Quantitative Research Findings' (2009) 11 International Studies Review 707.

60 James D Fearon and David D Latin, 'Violence and the Social Construction of Ethnic Identity' (2000) 544 International Organization 845; Paul Collier, Anke Hoeffler and Dominic Rohner, 'Beyond Greed and Grievance: Feasibility and Civil War' (2009) 61 Oxford Economic Papers 1.

${ }^{61}$ Evelyne Schmid and Aoife Nolan, “Do No Harm"?: Exploring the Scope of Economic and Social Rights in Transitional Justice' (2014) 8 International Journal of Transitional Justice 362.

${ }^{62}$ Lemkin (n 40), 80. Office of the UN Special Adviser on the Prevention of Genocide, 'Analysis Framework' 2009) <http://www.un.org/ar/preventgenocide/adviser/pdf/osapg_analysis_framework.pdf> (3 June 2019); CERD Committee, 'Decision on Follow up to the Declaration on the Prevention of Genocide: Indicators of Patterns of Systematic and Massive Racial Discrimination' (14 October 2005) CERD/C/67/1, paras 3, 14, 15. 
Nations urge that social rights violations and abuses be part of the aspects analyzed in conflict prevention ${ }^{63}$ and should be monitored in early warning strategies. ${ }^{64}$

The argument that abuses of social rights can contribute to the commission of international crimes can also be made in relation to torture outside the context of crimes against humanity, genocide or war crimes. The World Organization Against Torture published findings based on interdisciplinary and empirical research suggesting that socio-economic inequality and violence correlate with the commission of torture in significant ways. According to the study, '[s]tate violence, understood as political terror, torture and incarceration, is highly correlated with broader composite socio-economic indexes, with income as the single most powerful explanatory socio-economic factor' ${ }^{65}$ Of course, correlation does not mean causation and careful statistical analysis warns us against overly quick conclusions that tend to equate the two. ${ }^{66}$ Yet, the results prove that there are significant relationships between socio-economic deprivations and high levels of violence. Interestingly, for instance, the study found that improved water sources correlate with reduced levels of homicides with the use of a firearm, writing that '[i]mproved water sources alone can hardly explain homicides in a country, yet ...[e]conomic inequality is seen as a powerful variable in explaining the existence of violent crime such as homicides' ${ }^{67}$ These findings indicate that there are important links between weak social rights protection and the commission of crimes. Vice versa, the next section looks at the consequences of crimes on the protection and enjoyment of social rights.

\section{c. Consequences of International Crimes on Social Rights}

Unsurprisingly, the commission of international crimes can have negative consequences on social rights. International crimes usually imply a general decline in rights protection and the economic and social wellbeing of a large proportion of the population. Potentially, the commission of international crimes goes hand in hand with emigration of qualified personnel, decreases in the availability, accessibility and quality of health-care, education, social security [end of page 529] and public services in general and reduced possibilities for people to gain their economic livelihoods. Moreover, a state can face economic sanctions, e.g., if the UN Security Council finds that there is a threat to international peace and security and decides to adopt measures under Chapter VII of the UN Charter (such as in the cases of Iraq or North Korea $)^{68}$ or if individual states or regional organizations adopt trade or other economic sanctions.

At a more individual level, the commission of many international crimes can very severely affect the enjoyment of social rights of direct or indirect victims. It is well known, for instance, that the family members of a disappeared person often face significant problems in accessing social security or are prevented from access to land or other forms of inheritance ${ }^{69}$ In the absence of certainty about whether an individual has died (and thus, for instance, the possibility of getting a death certificate), family members face difficulties in obtaining pensions that a widow or a widower or their children would be

\footnotetext{
${ }^{63}$ Report of the Secretary-General, 'An Agenda for Peace: Preventive Diplomacy, Peacemaking and PeaceKeeping’ (17 June 1992) UN Doc A/47/277 - S/24111, paras 15, 18, 81.

64 OHCHR, 'Early Warning and Economic, Social and Cultural Rights' $<$ http://www.ohchr.org/Documents/Issues/ESCR/EarlyWarning_ESCR_2016_en.pdf> (3 June 2019).

${ }^{65}$ Thomas E McCarthy and World Organisation Against Torture, Attacking the Root Causes of Torture: Poverty, Inequality and Violence (2006).

${ }^{66} \mathrm{Ibid}$., at 35 .

${ }^{67}$ Ibid., at 42.

${ }^{68}$ UNSC Res S/RES/661 (6 August 1999) 'The Situation between Iraq and Kuwait'; UNSC Res S/RES/2397 (22 December 2017) 'Democratic People's Republic of Korea'.

${ }^{69} \mathrm{HRC}$, 'Report of the Working Group on Enforced or Involuntary Disappearances: Study on Enforced or Involuntary Disappearances and Economic, Social and Cultural Rights (9 July 2015)' UN Doc A/HRC/30/38/Add.5, para 23 .
} 
entitled to. These problems can be exacerbated by gender discrimination and stereotypes, particularly affecting women. According to the former Deputy UN High Commissioner for Human Rights: 'In societies where gender-based discrimination in laws and policies hinders the full realization of the human rights of women and limits their autonomy and participation in aspects of public and political life, the social and economic impact of disappearances is felt more strongly and, in turn, renders women and their children more vulnerable to exploitation and social marginalization. ${ }^{70}$

Other international crimes can negatively impact the enjoyment of social rights. Terrorism and ensuing counter-terrorism measures and policies can severely hamper the enjoyment of civil, cultural, economic, political or social rights. As an example, in the wake of terrorist crimes, governments have sometimes restricted the provision of humanitarian relief to areas in which the government suspected support for the alleged terrorists and evicted people or destroyed housing as a measure to counter terrorism. ${ }^{71}$ Other examples include the stigmatization and criminalization of social protests in the wake of terrorist crimes. These measures often seem to target particularly those protesting for social rights and groups such as trade unions, labour or women's rights movements and human rights defenders more broadly. ${ }^{72}$ [end of page 530]

\section{d. International Criminal Proceedings Impacting on Social Rights}

Last but not least, there are relationships between the existence of mechanisms relying on international criminal law (criminal proceedings, but also truth commissions, vetting strategies or reparations programs) and the enjoyment of social rights. These relations can be positive or negative.

On the negative side, transitional justice mechanisms, and particularly international criminal proceedings in international or hybrid courts, are expensive and thus have considerable opportunity costs. The ICC, for instance, is frequently reprimanded because of the financial costs incurred for each case. ${ }^{73}$ Rachel Kerr summarizes the pragmatic critique: The same resources could instead be spent on public services, development or reconstruction and it would seem dishonest not to mention that transitional justice measures can potentially have destabilizing effects. ${ }^{74}$ Unavoidable and difficult questions on prioritization, sequencing and selectivity arise. These are not questions that lawyers or other external experts should decide in The Hague, New York or Geneva. Rather, external actors should facilitate serious national consultations on transitional justice to resolve or at least deal with the thorny questions of who should focus on what at what moment, how and with what resources. ${ }^{75}$

On the other hand, the argument goes, the use of international criminal law can have positive effects on the enjoyment of human rights if the reliance on international criminal law contributes to the

70 OHCHR, 'Protecting Women from the Impact of Enforced Disappearances, 14 December 2012' $<$ http://www.ohchr.org/EN/NewsEvents/Pages/ProtectingWomenFromImpactOfEnforcedDisappearances.aspx $>$ (3 June 2019).

71 UN Counter-Terrorism Implementation Task Force Working Group Protecting Human Rights While Countering Terrorism, Expert Seminar on the Impact of Terrorism and Counter-Terrorism Measures on the Enjoyment of ESCR, Summary of Discussions (5-7 November 2008), para 25.

${ }^{72} \mathrm{Ibid}$., paras 26-30. The struggle over social rights and the targeting of those raising 'fears about dearth' is, e.g., well-documented for the French revolution. Charles Walton, 'Les graines de la discorde: Print, Public Spirit, and Free Market Politics in the French Revolution' in Charles Walton and Robert Darnton (eds), Into Print: Limits and Legacies of the Enlightenment (2011) 158, 169.

73 Bruno Cotte, 'La Cour pénale internationale' (2017) 11 La Revue des droits de l'homme $<$ http://journals.openedition.org/revdh/2776 > (3 June 2019).

${ }^{74}$ Rachel Kerr, 'International Criminal Justice' in Oilvera Simic (ed.), An Introduction to Transitional Justice (2017) 47, 57.

${ }^{75}$ In order to set legitimate priorities, the OHCHR recommends that good quality consultations are organized: OHCHR, Rule-of-Law Tools for Post-Conflict States: National Consultations on Transitional Justice (2009).. 
establishment or strengthening of the rule of law and signals an effective break with past abuses, increasing trust and leading to a state and a society that are more responsive to human rights concerns. ${ }^{76}$

\section{Current Developments, Challenges and Outlook}

Over the course of the last few years, the consideration for economic, social or cultural dimensions of international criminal law and transitional justice more broadly, has intensified. With very few exceptions, ${ }^{77}$ there is relative consensus that social rights have and should have some role to play in mechanisms relying on international criminal law and more broadly, transitional justice. ${ }^{78}$ Most notably, the Chief Prosecutor of the ICC, Fatou Bensouda, stated [end of page 531] in 2016 that her office 'will give particular consideration to prosecuting Rome Statute crimes that are committed by means of, or that result in, inter alia, the destruction of the environment, the illegal exploitation of natural resources or the illegal dispossession of land'. ${ }^{79}$ On behalf of victims' groups, a law firm filed a detailed communication in relation to forced evictions and forced dispossession of land in Cambodia - possibly constituting crimes against humanity overlapping with economic and social rights abuses. ${ }^{80}$ More recently, in 2018, Chief Prosecutor Bensouda requested a ruling by the Pre-Trial Chamber on whether the ICC has territorial jurisdiction over the deportation of Rohingya people from Myanmar to Bangladesh, ${ }^{81}$ perhaps leading to an investigation of the facts relating, inter alia, to the enjoyment of social rights by the Rohingyas. This could mean that the Office of the Prosecutor of the ICC might increasingly take into account allegations that relate to social rights abuses.

At the same time, it would be very unrealistic to expect the ICC to play a significant role in the protection of social rights. The ICC faces many challenges, not all of which can be controlled by the Court, as some of the challenges are due to structural peculiarities in international relations (in particular the difficulties to enforce arrest warrants and to persuade unwilling states to cooperate). The ICC and the multilateral efforts for a global judiciary and international law in general are currently in a crisis whose outcome cannot yet be assessed. Successful attempts to severely restrict the budget of the ICC ${ }^{82}$ and the disappointments with the ICC's performance over the first twenty years of the Court, as well as withdrawals, could lead to an additional decline in support for the institutions of international criminal

\footnotetext{
${ }^{76}$ Kathryn Sikkink, Justice Cascade: How Human Rights Prosecutions Are Changing World Politics (2012). See also the concluding paragraphs of section IV below for the argument on the expressive capacity of approaches based on international criminal law.

${ }^{77}$ Notably Waldorf (n 29).

${ }^{78}$ For overviews of the debate, Juan Carlos Ochoa-Sánchez, 'Economic and Social Rights and Transitional Justice: A Framework of Analysis' (2019) Journal of Human Rights $<$ https://doi.org/10.1080/14754835.2019.1609349> (16 July 2019); Clara Sandoval-Villalba, 'Reflections on the Transformative Potential of Transitional Justice and the Nature of Social Change in Times of Transition' in Roger Duthie and Paul Seils (eds), Justice Mosaics: How Context Shapes Transitional Justice in Fractured Societies (ICTJ 2017) 166, 168; Barrie Sander, 'Addressing the Economic Dimensions of Mass Atrocities: International Criminal Law's Business or Blind Spot?' (Justice in Conflict, 8 June 2015) <https:/justiceinconflict.org/2015/06/08/addressing-the-economic-dimensions-of-massatrocities-international-criminal-laws-business-or-blind-spot/> (3 June 2019).

${ }^{79}$ Office of the Prosecutor of the International Criminal Court, Policy Paper on Case Selection and Prioritisation (2016), para 41.

${ }^{80}$ Global Dilligence LLP, 'Cambodia: ICC Preliminary Examination Requested into Crimes Stemming from Mass Land Grabbing' (2014) <http://www.globaldiligence.com/2014/10/07/global-diligence-file-article-15communication-international-criminal-court/> (3 June 2019).

${ }^{81}$ Request for a Ruling on Jurisdiction under Article 19(3) of the Statute, 9 April 2018 (ICC).

${ }^{82}$ And the ICC's own contribution to this situation: Amnesty International, 'Don't Ask and You Won't Receive - Will the ICC Request the Resources It Needs in 2019?' 2018) <https://hrij.amnesty.nl/icc-zero-growth-dontask-and-you-wont-receive/> (3 June 2019).
} 
law. ${ }^{83}$ Furthermore, a continuing lack of appetite from domestic prosecutors and tribunals to engage with international criminal law, let alone those types of underlying facts and rights abuses that are not the focus of much contemporary attention, means that the impact of these mechanisms on social rights protection remains uncertain.

In any event, international criminal law is not a panacea. Just because there are manifold relationships between social rights and international criminal law - including overlap between social rights abuses and international offences - does not mean that it would necessarily be a good idea for the ICC, truth commissions or other mechanisms to begin uncritically focusing on social rights. Rather, there are important limitations of relying on international criminal law for the purpose of remedying social rights abuses and enhancing their protection. It is difficult [end of page 532] to obtain remedies for victims and international criminal law is ill-suited as a stand-alone tool for social change. As mentioned at the outset, international criminal law focuses on the binary question of whether or not certain objective and mental elements are present in order to assess whether an international crime has been committed or not. Criminal proceedings based on international criminal law operate within narrow confines given that criminal sanctions impose constraints on important legal interests, such as the liberty or property of the individual who is convicted of a crime. Truth commissions, reparations programs or commissions of inquiry have more leeway, particularly when they do not single out individual perpetrators but 'merely' make factual and legal findings on the (in)existence of grounds to believe that international crimes have been committed.

Another concern that must be raised is that relying on international criminal law in relation to human rights concerns carries a risk of downgrading other serious human rights problems. ${ }^{84}$ As mentioned, by far not every - even very serious - human rights violation constitutes an international crime. From a human rights perspective, it is clearly not justifiable that only those abuses that states decided to declare international crimes should merit attention.

The legal argument that some social rights violations and abuses simultaneously constitute international crimes does, however, justify one important recommendation: alleged crimes related to social rights enjoyment should be taken seriously - for the same reasons for which we take other crimes under international criminal law seriously. Hence, it is, for instance, legally inaccurate if legal advisors tell survivors, truth commissioners or others that international criminal law must automatically and always lead to an inevitable focus on a few civil and political rights. If a truth commission, for instance, has a mandate covering crimes against humanity, it is legally erroneous to conclude that nothing can be done to address or at least analyze social rights considerations from an international criminal perspective. In addition, links between international criminal law and social rights should play a conscious role in the work of policy analysts, journalists or NGOs reporting on abuses. It plays a crucial role whether they describe the hunger in Cambodia during the Khmer regime as the result of a presumed crime, or whether hunger is presented as 'mere' contextual information. ${ }^{85}$ If social rights abuses are presented without reflection as contextual background information or 'only' as a consequence of other abuses, this is an implicit signal to the affected population that these abuses cannot be analyzed on their own terms (and consequently, that the affected individuals are not victims of legally relevant conduct unless they also faced abuses of civil and political rights). This underscores the tendency to view civil and political rights

\footnotetext{
${ }^{83}$ Douglas Guilfoyle, 'This Is Not Fine: The International Criminal Court in Trouble (three-part series of blog posts)' (EJIL: Talk!, 21, 22 and 25 March 2019) <https://www.ejiltalk.org/part-iii-this-is-not-fine-theinternational-criminal-court-in-trouble/> (3 June 2019).

${ }^{84}$ Clapham (n 19), 18.

${ }^{85}$ Randle DeFalco, 'Accounting for Famine at the Extraordinary Chambers in the Courts of Cambodia: The Crimes against Humanity of Extermination, Inhumane Acts and Persecution' (2011) 5 International Journal of Transitional Justice 142. On the framing issues of abuses/crimes versus contextual background information, see Sam Szoke-Burke, "Not Only "Context": Why Transitional Justice Programs Can No Longer Ignore Violations of Economic and Social Rights’ (2015) 50 Texas International Law Journal 465.
} 
abuses as the forefront issues when discussing human rights and conflicts, with social rights abuses constituting their context and consequences. Even if not intended, such framings can be water on the mills of those who present social rights as mere political fair-weather ambitions rather than legal rights. ${ }^{86}$ Therefore, care should be taken to avoid portraying all social rights problems 'merely' as context, consequences or needs. [end of page 533]

Why is this important? The recognition that social rights interact with international criminal law and that violations of social rights can sometimes amount to international criminal offences serves a potentially powerful expressive purpose. Mark Drumbl eloquently describes how international criminal law has the potential to enhance "expressive value in asserting the importance of law, the stigmatization of the offender who transgresses that law, and the authenticity of the historical narrative that ensues' ${ }^{87}$ For better or worse, international criminal law is 'able to mobilize authority in ways that make it more powerful at a global level' than other approaches employed to address the legacies left behind by a violent past. ${ }^{88}$ In a recent empirical study, political scientist Tine Destrooper examined the 'expressive relevance' of the lack of incorporating social and economic rights considerations in the Extraordinary Chambers of in the Courts of Cambodia (ECCC). Destrooper used structural topic modelling 'to examine how the prioritization of civil and political rights issues by the [ECCC] affected the agendas of Cambodian human rights NGOs with an international profile'. She found that these NGOs' focus on a small range of civil and political rights issues can be traced back to the near-exclusive focus on the same issues by the ECCC. The ECCC thus systematically disregarded economic, social and cultural rights aspects. This neglect triggered a similar blind spot for socio-economic and cultural rights issues on the side of human rights NGOs who could have potentially played an important role in creating or amplifying a debate on the accountability around social rights. ${ }^{89}$ Arguably, this is a missed opportunity. If the ECCC had considered social rights relevant conduct, the opposite effect would have likely taken place, i.e. civil society might have taken up an active role with regards to social rights - which would have been in tune with the wishes of large proportions of the Cambodian population according to population surveys. ${ }^{90}$ If the focus of a tribunal has such a significant influence on the work and discourse of civil society actors in a given context, ${ }^{91}$ these recent findings support the idea that the expressive potential of addressing at least some social rights issues in international criminal law has the potential to contribute, at least in a modest way, in putting social rights on the political agenda and enhance their protection. [end of page 534]

\footnotetext{
${ }^{86}$ Schmid and Nolan (n 61).

${ }^{87}$ Mark Drumbl, Atrocity, Punishment, and International Law (2007) 175. Expressive theories of international criminal law go back notably to Joel Feinberg, 'The Expressive Function of Punishment' (1965) 49 The Monist 397.

${ }^{88}$ Peter Dixon and Chris Tenove, 'International Criminal Justice as a Transnational Field: Rules, Authority and Victims' (2013) 7 International Journal of Transitional Justice 393, 393.

89 Tine Destrooper, 'Neglecting Social and Economic Rights Violations in Transitional Justice: Long-Term Effects on Accountability' (2018) 37 Journal of Current Southeast Asian Affairs 95.

${ }^{90}$ Most notably Phuong Pham et al., So We Will Never Forget: A Population-Based Survey on Attitudes About Social Reconstruction and the Extraordinary Chambers in the Courts of Cambodia (Human Rights Center, University of California Berkeley 2011) 45.

91 \#\#Refer to Daniela Ikawa's chapter on civil society
} 